Supplement of Atmos. Chem. Phys., 19, 5805-5833, 2019

https://doi.org/10.5194/acp-19-5805-2019-supplement

(C) Author(s) 2019. This work is distributed under

the Creative Commons Attribution 4.0 License.

(c) (1)

Supplement of

\title{
Mechanism of ozone loss under enhanced water vapour conditions in the mid-latitude lower stratosphere in summer
}

Sabine Robrecht et al.

Correspondence to: Sabine Robrecht (sa.robrecht@ fz-juelich.de)

The copyright of individual parts of the supplement might differ from the CC BY 4.0 License. 


\section{Case of high $\mathrm{Cl}_{\mathrm{y}}$}

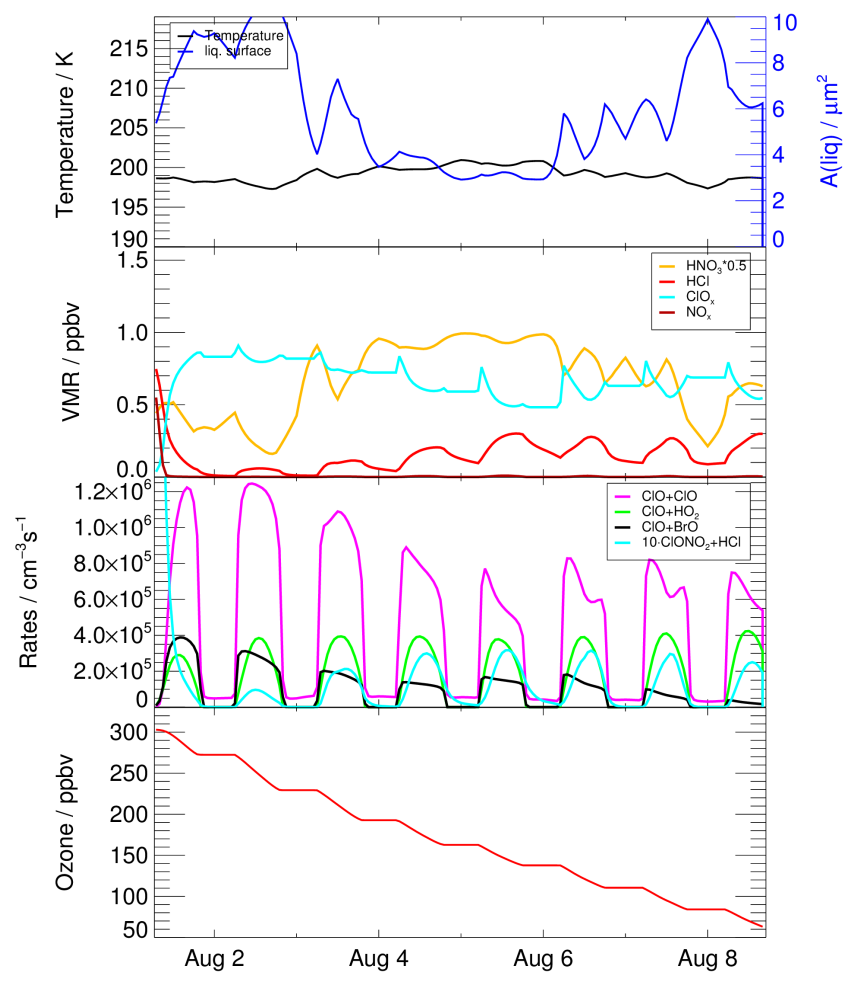

Figure 1: Behaviour under "Case of high $\mathrm{Cl}_{y}$ " conditions assuming high values for $\mathrm{Cl}_{y}$ and $\mathrm{NO}_{y}$ (see Tab. 1). Presented is the volume mixing ratio of ozone, temperature, liquid surface density, mixing ratio of $\mathrm{HNO}_{3}$ (scaled by $0.5), \mathrm{HCl}, \mathrm{ClO}_{x}$ and $\mathrm{NO}_{x}$ and reaction rates of reactions essential for chlorine activation and catalytic ozone loss cycles $\left(\mathrm{ClONO}_{2}+\mathrm{HCl}\right)$ and the reactions $\mathrm{ClO}+\mathrm{BrO}, \mathrm{ClO}+\mathrm{ClO}$ and $\mathrm{ClO}+\mathrm{HO}_{2}$. The x-axis ticks refer to 00:00 local time (06:00 UCT) of that day.

Comparing the standard case and the high $\mathrm{Cl}_{y}$ case using 15 ppmv water vapour conditions, in the high $\mathrm{Cl}_{y}$ case more inactive chlorine is converted 
into active $\mathrm{ClO}_{x}$ on the first day of the simulation (Fig.1). This higher $\mathrm{ClO}_{x}$ mixing ratio results in faster catalytic ozone loss cycles with peak values of $3.9 \cdot 10^{5} \mathrm{~cm}^{-3} \mathrm{~s}^{-1}$ for the reaction $\mathrm{ClO}+\mathrm{HO}_{2}, 2.0 \cdot 10^{5} \mathrm{~cm}^{-3} \mathrm{~s}^{-1}$ for the reaction $\mathrm{ClO}+\mathrm{BrO}$ and $10.9 \cdot 10^{5} \mathrm{~cm}^{-3} \mathrm{~s}^{-1}$ for $\mathrm{ClO}+\mathrm{ClO}$ on $3 \mathrm{Aug} 2013$. Since the $\mathrm{Cl}_{y^{-}}$ mixing ratio is much higher than in the standard case, the catalytic ozone loss cycles are dominated by the $\mathrm{ClO}$-Dimer cycle and result in a much larger ozone loss than in the standard case assuming realistic $\mathrm{Cl}_{y}$ and $\mathrm{NO}_{y}$ mixing ratios. 


\section{Reduced $\mathrm{Br}_{y}$ Case}

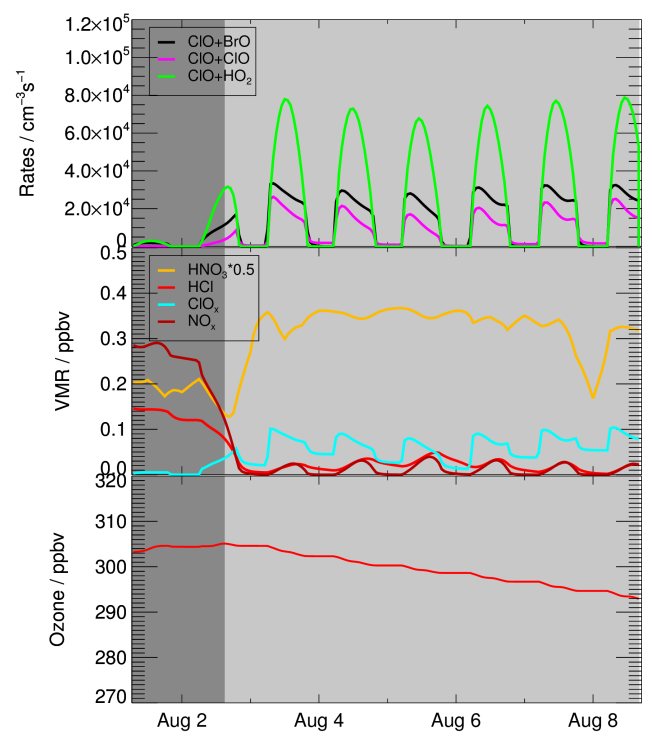

Figure 2: Impact of a $\mathrm{Br}_{y}$ reduction on the ozone loss process. The volume mixing ratio of ozone, the mixing ratio of $\mathrm{HNO}_{3}$ (scaled by 0.5 ), $\mathrm{HCl}, \mathrm{ClO}_{x}$ and $\mathrm{NO}_{x}$ and reaction rates of reactions essential for chlorine activation and catalytic ozone loss cycles $\left(\mathrm{ClONO}_{2}+\mathrm{HCl}\right)$ and the reactions $\mathrm{ClO}+\mathrm{BrO}$, $\mathrm{ClO}+\mathrm{ClO}$ and $\mathrm{ClO}+\mathrm{HO}_{2}$. The x-axis ticks refer to 00:00 local time (06:00 UCT) of that day.

In the case of reduced $\mathrm{Br}_{y}$, the catalytic ozone destruction in the $\mathrm{ClO}-\mathrm{BrO}$ cycle $(\mathrm{ClO}+\mathrm{BrO})$ is reduced (Fig. 2), while the rates of further reactions , which yield catalytic ozone loss, $\left(\mathrm{ClO}+\mathrm{ClO}\right.$ and $\left.\mathrm{ClO}+\mathrm{HO}_{2}\right)$ are similar to those of the standard case. This results in a reduced ozone destruction in the $0.5 \mathrm{Br}_{y}$ case regarding the standard case. 


\section{$3 \quad$ Extended time period}

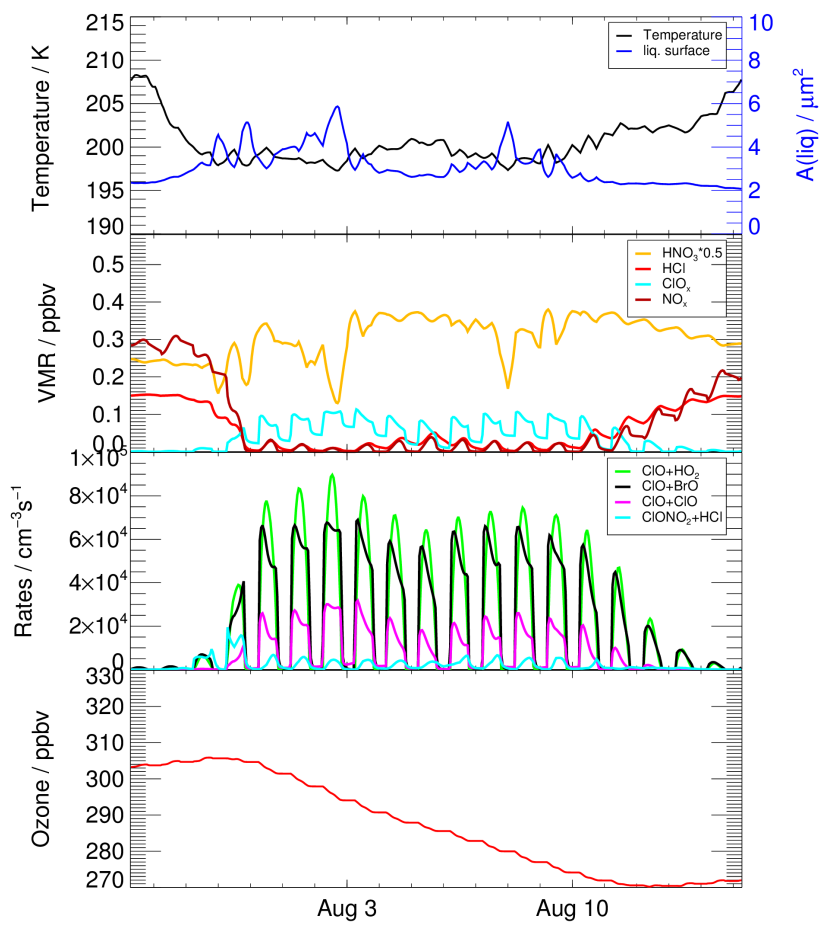

Figure 3: Temperature and chemical behavior for the 19-day simulation. Temperature, liquid surface area, the mixing ratio of ozone, $\mathrm{HNO}_{3}$ (scaled by $0.5), \mathrm{HCl}, \mathrm{ClO}_{x}$ and $\mathrm{NO}_{x}$ and reaction rates of reactions essential for chlorine activation $\left(\mathrm{ClONO}_{2}+\mathrm{HCl}\right)$ and catalytic ozone loss cycles $\left(\mathrm{ClONO}_{2}+\mathrm{HCl}\right)$ and the reactions $\mathrm{ClO}+\mathrm{BrO}, \mathrm{ClO}+\mathrm{ClO}$ and $\mathrm{ClO}+\mathrm{HO}_{2}$ are shown for the 19-day simulation. The $\mathrm{x}$-axis ticks refer to 00:00 local time (06:00 UCT) of that day.

On 27 July 2013, the 19-day simulation starts at a temperature of $208 \mathrm{~K}$ (Fig.3, right), decreasing until 29 July 2013 to lower than $200 \mathrm{~K}$. The temperatures remain lower than $201 \mathrm{~K}$ until 11 August and increase to over $205 \mathrm{~K}$ 
on 14 August 2013.

Assuming a water vapour mixing ratio of $15 \mathrm{ppmv}$, chlorine activation occurs on 30 July 2013, after the temperatures fall below $200 \mathrm{~K}$ (Fig.3, right). The mixing ratio of $\mathrm{NO}_{x}$ remains low and $\mathrm{ClO}_{x}$ remains high until 11 August, when the heterogeneous reaction rate of $\left(\mathrm{ClONO}_{2}+\mathrm{HCl}\right)$ decreases due to higher temperatures. For this reason chlorine activation cannot anymore be maintained. Thus, the time span holding a $\mathrm{ClO}_{x}$ mixing ratio high enough for the occurrence of catalytic ozone loss cycles comprises 14 days and ozone destruction stops on 12 August. 